Endrik Nurrohman, Abdulkadir Rahardjanto, Sri Wahyuni. (2018). Studi Hubungan Keanekaragaman Makrofauna Tanah dengan Kandungan C-Organik dan Organophosfat Tanah di Perkebunan Cokelat (Theobroma cacao L.) Kalibaru Banyuwangi. Jurnal Bioeksperimen. Vol. 4 (1) Pp. 1-10. Doi: https://doi.org/10.23917/bioeksperimen.v4i1.2795

\title{
Studi Hubungan Keanekaragaman Makrofauna Tanah dengan Kandungan C-Organik dan Organophosfat Tanah di Perkebunan Cokelat (Theobroma cacao L.) Kalibaru Banyuwangi
}

\author{
Endrik Nurrohman*, Abdulkadir Rahardjanto, Sri Wahyuni \\ Pendidikan Biologi FKIP Universitas Muhammadiyah Malang \\ Jl. Raya Tlogomas No. 246 Fax. 0341-460435 Malang 65144 \\ *Email: endrik.18@gmail.com
}

\begin{abstract}
This type of research is descriptive quantitative research. The research was conducted on February-March 2015. The purpose of this study was to determine the diversity of soil macrofauna, C-organic content of the soil and organophosfat. The method in this study is the trap (Pitt fall Trap) to determine the diversity of soil macrofauna and laboratory analysis to determine the content of C-Organic and organophosfat ground. The results showed that (1) density ranged from $0.25 \mathrm{ind} / \mathrm{m} 2-4,75 \mathrm{ind} / \mathrm{m} 2$, relative density ranging from 0.002 to 0.052 . Frequency ranges from 0.16 to 1.00 , the relative frequency ranged from 0.018 to 0.115 . Shannon wiener species diversity index $\left(H^{\prime}\right)$ category of low species diversity. Test Results $C$-Organic soil is very high meaning the land classified as arable land. Organophosfat kind Carbokfuran very high.
\end{abstract}

Keywords: Soil Macrofauna Diversity, C-Organic, Organophosfat.

\begin{abstract}
Abstrak
Jenis penelitian yang digunakan adalah penelitian deskriftif kuantitatif. Penelitian ini dilakukan pada bulan FebruariMaret 2015. Tujuan penelitian ini adalah untuk mengetahui keanekaragaman makrofauna tanah, kandungan C-organik dan organophosfat tanah. Metode dalam penelitian ini adalah jebakan (pitt fall trap) untuk mengetahui keanekaragaman makrofauna tanah dan analisis laboratorium untuk mengetahui kandungan C-Organik dan organophosfat tanah. Hasil penelitian menunjukkan bahwa (1) Kepadatan berkisar antara $0,25 \mathrm{ind} / \mathrm{m}^{2}-4,75 \mathrm{ind} / \mathrm{m}^{2}$, kepadatan relatif berkisar antara 0,002-0,052. Frekuensi berkisar antara 0,16-1,00, frekuensi relatif berkisar antara 0,018-0,115. Indeks keanekaragaman jenis Shannon wiener ( $\left.\mathrm{H}^{\prime}\right)$ kategori keanekaragaman jenis rendah. Hasil Uji C-Organik tanah sangat tinggi berarti tanah tergolong tanah yang subur. Organophosfat jenis Carbokfuran sangat tinggi.
\end{abstract}

Kata kunci: Keanekaragaman makrofauna tanah, C-Organik, Organophosfat.

\section{Pendahuluan}

Biodiversitas suatu kawasan merupakan fungsi dari diversitas lokal atau habitat tertentu dan struktur yang ada di dalamnya pada daerah terestial (Suwondo, 2007). Biodiversitas tanah merupakan salah satu bentuk diversitas alfa yang sangat berperan dalam mempertahankan dan meningkatkan fungsi tanah untuk menopang kehidupan di dalamnya (Giller et al., 1997). Pemahaman tentang biodiversitas tanah masih sangat terbatas, baik dari segi taksonomi maupun fungsi ekologinya maka diperlukan upaya untuk mengkaji dan sekaligus melestarikannya (Sugiyarto, 2000).
Biodiversitas fauna tanah adalah hewan-hewan yang hidup di atas maupun di bawah permukaan tanah (Bruyn, 1997). Berdasarkan ukuran tubuhnya, fauna tanah dapat dibedakan menjadi empat kelompok, yaitu mikrofauna, mesofauna, makrofauna megafauna (Nusroh, 2007). Brussaard (1998) membedakan tiga kelompok fungsional organisme tanah, yaitu: biota akar (mikorizha, rhizobium, nematoda, dan lain-lain); dekomposer (mikroflora, mikrofauna, dan mesofauna); dan "ecosystem engineer" (mesofauna dan makrofauna).

Peran aktif makrofauna tanah dalam menguraikan bahan organik tanah dapat mempertahankan dan mengembalikan 
produktivitas tanah dengan didukung faktor lingkungan di sekitarnya (Wulandari dkk., 2005). Keberadaan dan aktivitas makrofauna tanah dapat meningkatkan aerasi, infiltrasi air, agregasi tanah, serta mendistribusikan bahan organik tanah sehingga diperlukan suatu upaya untuk meningkatkan keanekaragaman makrofauna tanah (Njira \& Nabwami, 2013). Makrofauna seperti cacing dan sejenisnya berperan dalam siklus energi dalam ekosistem (Bruyn, 1997).

Makrofauna tanah berperan penting dalam meningkatkan kadar bahan organik tanah, umumnya kelimpahan makrofauna disebabkan oleh beberapa faktor, di antaranya tanaman penutup (Merlim et al, 2005). Keberadaan fauna tanah sangat dipengaruhi oleh kondisi tanah, salah satunya adalah adanya bahan organik dalam tanah (Putra, 2012). Keberadaan fauna dapat dijadikan parameter dari kualitas tanah, fauna tanah yang digunakan sebagai bioindikator kesuburan tanah tentunya memiliki jumlah yang relatif melimpah (Ibrahim, 2014).

Menurut Hanafiah (2013) kesuburan tanah juga dipengaruhi oleh ketersediaan hara, rendahnya ketersediaan hara mencerminkan rendahnya kesuburan tanah sehingga keberadaan makrofauna tanah sebagai perombak bahan organik sangat menentukan ketersediaan hara dalam menyuburkan tanah. Salah satu fauna tanah yang dapat dijadikan bioindikator adalah makrofauna tanah. Masing-masing biota tanah mempunyai fungsi yang khusus dan mempunyai fungsi ekologis yang khusus (Paritika, 2010). Setiap grup fauna tanah dapat dijadikan bioindikator karena keberadaan fauna tanah sangat bergantung dengan faktor biotik dan abiotik tanah (Sugiyarto, 2010). Makrofauna tanah mempunyai peranan besar untuk memperbaiki sifat-sifat fungsional tanah (Nusroh, 2000).

Keanekaragaman suatu hewan juga dipengaruhi oleh adanya bahan kimia berbahaya dalam tanah, bahan kimia berdampak negatif pada keseimbangan ekosistem (Untung, 2006). Bahan kimia dapat menimbulkan berbagai permasalahan salah satunya menyebabkan kepunahan pada jenis-jenis makrofauna tanah tertentu yang berdampak pada kurangnya keanekaragaman jenis makrofauna tanah yang ada di ekosistem Rahmawati (2012).

Penelitian makrofauna tanah terutama yang terdapat pada lahan perkebunan cokelat masih sedikit dilakukan. Tanaman cokelat yang berada di Banyuwangi merupakan kawasan perkebunan cokelat yang paling luas di Jawa Timur, Terbatasnya penelitian makrofauna ini dikuatkan oleh Lavelle et al (2000) meskipun telah banyak yang melaporkan tentang peran makrofauna tanah dalam sistem reproduksi tanaman pertanian, tetapi perhatian pada perlunya melakukan konservasi terhadap biodiversitas makrofauna tanah masih sangat terbatas. Banyak tema penelitian yang masih perlu dilakukan guna meningkatkan kelestarian dan daya manfaat makrofauna tanah (Sugiyarto, 2000).

Penelitian ini bertujuan untuk mengetahui hubungan antara keanekaragaman makrofauna tanah dengan kandungan c-organik dan organophosfat tanah di perkebunan cokelat (Theobroma cacao L.) yang ada di kecamatan Kalibaru kabupaten Banyuwangi.

\section{Metode Penelitian}

Jenis Penelitian ini adalah deskriptif kuantitatif. Tujuan penelitian ini adalah untuk mengetahui keanekaragaman makrofauna tanah, kandungan C-organik dan organophosfat tanah. Penelitian ini dilakukan pada Maret-April 2015 di perkebunan cokelat (Theobroma cacao L.) Kecamatan Kalibaru Kabupaten Banyuwangi. Metode jebakan (pitt fall trap) untuk mengetahui keanekaragaman makrofauna tanah dan analisis laboratorium untuk mengetahui kandungan C-Organik dan organophosfat tanah. Populasi dalam penelitian ini adalah semua hewan makrofauna tanah yang ditemukan pada lokasi penelitian. Sampel dalam penelitian ini adalah makrofauna tanah yang ditemukan pada setiap stasiun penelitian. Teknik sampling menggunakan simple random sampling, penelitian ini dilakukan pada 6 stasiun masing-masing stasiun terdiri dari 4 jebakan.

Penelitian dilakukan melalui beberapa tahapan yaitu penentuan lokasi penelitian dan dilanjutkan dengan pemetaan untuk 
menentukan stasiun dan ulangan/pit fall trap. Makrofauna tanah yang terkoleksi diidentifikasi dengan mengacu pada buku Pengenalan Serangga Borror et al., (1992), dan Buku Calssification of Insects Brues et al., (1954) dan diidentifikasi di Laboratorium Diversitas FMIPA Universitas Brawijaya Malang. Tanah diuji kandungan C-Organik dan Organophosfat di Laboratorium kimia Universitas Muhammadiyah Malang. Data makrofauna yang sudah terkumpul dihitung indeks keanekaragaman menggunakan rumus shannon weiner yaitu $H^{`}=\Sigma$ pi $\ln$ pi; di mana pi: merupakan rasio antara jumlah/ dominansi individu suatu spesies dengan jumlah/dominansi total semua spesies.

\section{Hasil Dan Pembahasan}

\section{Jenis-Jenis Mesofauna Tanah yang Ditemukan}

Jenis-jenis makrofauna tanah yang terkoleksi terdiri dari 7 kelas dengan 14 Bangsa dan tergolong dalam 17 Suku 20 Marga dan 20 jenis (tabel 1).

Tabel 1 Makrofauna yang terkoleksi

\begin{tabular}{|c|c|c|c|c|c|c|c|c|c|c|c|}
\hline \multirow[t]{2}{*}{ No } & \multirow[t]{2}{*}{ Kelas } & \multirow[t]{2}{*}{ Ordo } & \multirow[t]{2}{*}{ Suku } & \multirow[t]{2}{*}{ Marga } & \multirow[t]{2}{*}{ Jenis } & \multicolumn{6}{|c|}{$\begin{array}{c}\text { Jumlah Individu Stasiun } \\
\text { Penelitian }\end{array}$} \\
\hline & & & & & & 1 & 2 & 3 & 4 & 5 & 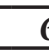 \\
\hline \multirow{12}{*}{1} & \multirow{12}{*}{ Insecta } & Orthroptera & Gryllotalpidae & Gryllotalpa & $\begin{array}{l}\text { Gryllotalpa } \\
\text { grillotalpa }\end{array}$ & 0 & 1 & 0 & 0 & 0 & c \\
\hline & & \multirow{4}{*}{ Hymenoptera } & Gryllinae & Gryllus & Gryllus sp & 1 & 0 & 0 & 0 & 1 & 2 \\
\hline & & & \multirow{3}{*}{ Formicidae } & Odontoponera & $\begin{array}{l}\text { Odontoponera } \\
\text { denticulata }\end{array}$ & 3 & 0 & 0 & 2 & 1 & c \\
\hline & & & & Odontomanchus & $\begin{array}{l}\text { Odontoman- } \\
\text { chussp }\end{array}$ & 0 & 0 & 1 & 0 & 0 & c \\
\hline & & & & Componotus & $\begin{array}{l}\text { Componotus } \\
\text { arogans }\end{array}$ & 0 & 1 & 1 & 2 & 1 & 2 \\
\hline & & Dermaptera & Forficulidae & Forficula & $\begin{array}{l}\text { Forficula } \\
\text { auricularia }\end{array}$ & 1 & 1 & 0 & 0 & 0 & 1 \\
\hline & & & Scarabaeidae & Phyllophaga & Phyllopaga sp & 0 & 0 & 0 & 1 & 0 & 1 \\
\hline & & Coleoptera & Hydrophilidae & Hidrochara & $\begin{array}{l}\text { Hidrochara } \\
\text { soror }\end{array}$ & 0 & 2 & 0 & 1 & 1 & 1 \\
\hline & & \multirow{3}{*}{ Hemiptera } & Meloidae & Tachyta & $\begin{array}{l}\text { Tachyta angu- } \\
\text { lata }\end{array}$ & 1 & 0 & 1 & 0 & 1 & 1 \\
\hline & & & Pyrrhocoridae & Ploiaria & Ploiaria sp & 0 & 0 & 1 & 0 & 0 & c \\
\hline & & & coreidae & Leptocarisa & $\begin{array}{l}\text { Leptocorisa } \\
\text { acuta }\end{array}$ & 0 & 1 & 0 & 0 & 0 & ( \\
\hline & & Blattaria & $\begin{array}{l}\text { Cryptocerci- } \\
\text { dae }\end{array}$ & Cryptocercus & $\begin{array}{l}\text { Cryptocercus } \\
\text { garciai }\end{array}$ & 1 & 0 & 0 & 0 & 0 & c \\
\hline 2 & Hexapoda & Coleoptera & Chrysomelidae & Systena & Systena sp & 1 & 0 & 0 & 1 & 1 & 1 \\
\hline \multirow{2}{*}{3} & \multirow[t]{2}{*}{ Diplopoda } & Polydesmida & Xystodesmidae & Sigmoria & $\begin{array}{l}\text { Sigmoria } \\
\text { trimaculata }\end{array}$ & 1 & 0 & 0 & 1 & 1 & ( \\
\hline & & Spirobolida & Trigoniulidae & Trigoneulus & $\begin{array}{l}\text { Trigoneolus } \\
\text { corallinus }\end{array}$ & 0 & 1 & 1 & 1 & 1 & 1 \\
\hline 4 & Arachnida & Araneae & Lycosidae & Pirata & $\begin{array}{l}\text { Pirata pirat- } \\
\text { icus }\end{array}$ & 4 & 6 & 7 & 0 & 2 & c \\
\hline 5 & Citellata & Haplotaxida & Lumbricidae & Lumbricus & $\begin{array}{l}\text { Lumbricus } \\
\text { rubellus }\end{array}$ & 0 & 0 & 0 & 0 & 0 & 1 \\
\hline \multirow[t]{2}{*}{6} & \multirow[t]{2}{*}{ Chilopoda } & $\begin{array}{l}\text { Scolopendro- } \\
\text { morpha }\end{array}$ & $\begin{array}{l}\text { Scolopendri- } \\
\text { dae }\end{array}$ & Scolopendra & $\begin{array}{l}\text { Scolopendra } \\
\text { gigantea }\end{array}$ & 4 & 2 & 3 & 3 & 3 & c \\
\hline & & $\begin{array}{l}\text { Geophilomor- } \\
\text { pha }\end{array}$ & Geophilidae & Geophilus & Geophilus sp & 2 & 1 & 1 & 2 & 0 & 1 \\
\hline \multirow[t]{2}{*}{7} & $\begin{array}{l}\text { Gastrop- } \\
\text { oda }\end{array}$ & $\begin{array}{l}\text { Stylommato- } \\
\text { phora }\end{array}$ & Lymnaeidae & Lymnaea & $\begin{array}{l}\text { Lymnaea } \\
\text { rubiginosa }\end{array}$ & 1 & 1 & 1 & 0 & 0 & c \\
\hline & & & Jumlah & & & 19 & 17 & 17 & 13 & 13 & 12 \\
\hline
\end{tabular}


Berdasarkan Tabel 1 diperoleh dua kelas makrofauna tanah yang terdiri dari jenis-jenis makrofauna tanah yang terkoleksi terdiri dari 7 kelas dengan 14 Bangsa dan tergolong dalam 17 Suku 20 Marga dan 20 jenis berbeda yang ditemukan di lokasi penelitian. Jenis makrofauna tanah yang ditemukan di stasiun yang berbeda dapat disebabkan karena mesofauna tanah tersebut bersifat mobile (bergerak), sehingga bila kondisi lingkungan tidak baik maka makrofauna tanah tersebut akan berpindah tempat. Keberadaan fauna tanah sangat dipengaruhi oleh faktor lingkungan yaitu faktor biotik dan faktor abiotik. Faktor lingkungan abiotik yang mempengaruhi adalah faktor fisika antara lain tekstur tanah, struktur tanah, dan faktor kimia antara lain $\mathrm{pH}$, salinitas, kadar bahan organik dan unsur mineral tanah. Sedangkan faktor biotik yang mempengaruhi antara lain mikroflora dan tanaman. Tanaman dapat meningkatkan kelembaban tanah dan sebagai penghasil serasah yang disukai fauna tanah (Nusroh, 2007).

\section{Indeks Keanekaragaman (Diversity) Makrofauna Tanah}

Hasil keanekaragaman makrofauna tanah pada stasiun I, II, III, IV, V dan VI tersajikan pada Gambar 1. berikut.

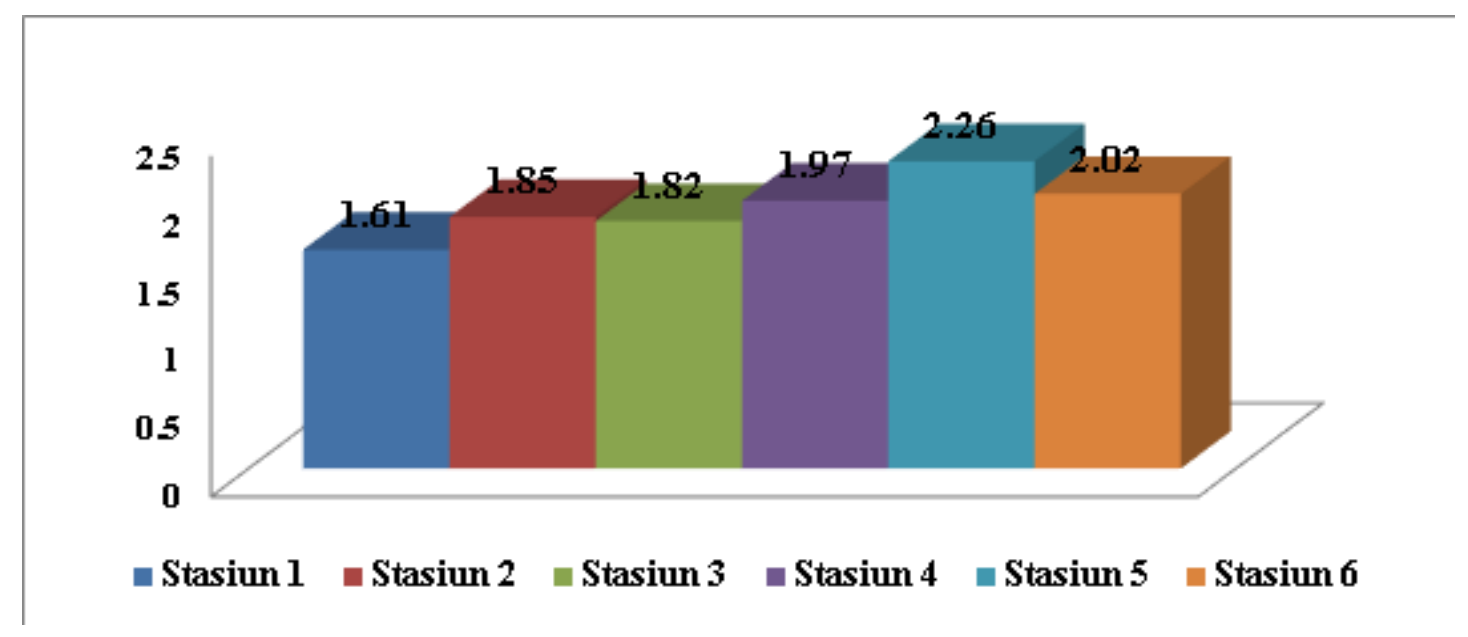

Gambar 1. Indeks keanekaragaman mesofauna tanah pada 6 stasiun penelitian

Berdasarkan grafik di atas diketahui bahwa 4 stasiun dari 6 stasiun berada dalam kategori dengan nilai indeks keanekaragaman yang rendah, hal tersebut karena memang lokasi penelitian merupakan lokasi dengan keadaan yanh homogen. Menurut Fatawi (2002) semakin heterogen dan kompleks suatu daerah atau lingkungan secara fisik maka semakin tinggi tingkat keanekaragaman jenisnya. Selain itu faktor biotik dan abiotik dari lingkungan juga mempengaruhinya. Sugiyarto (2000) keanekaragaman makrofauna tanah menunjukkan korelasi tinggi dengan kandungan bahan organik tanah. Suin (2012) mengungkapakan rendahnya nilai indeks keanekaragaman (diversity) kemungkinan besar dipengaruhi oleh faktor-faktor lingkungan abiotik.

Perhitungan tentang indeks keanekaragaman bertujuan untuk mengetahui derajat keanekaragaman suatu komunitas jenis makrofauna dan untuk mempelajari pengaruh gangguan-gangguan faktor-faktor lingkungan atau abiotik terhadap komunitas (Fachrul, 2012). Keanekaragaman jenis ditunjukkan oleh banyaknya jenis organisme yang membentuk komunitas di kawasan tertentu. Suatu komunitas dikatakan memiliki keanekaragaman yang tinggi jika komunitas itu disusun oleh banyak jenis begitu juga sebaliknya (Odum, 1993). Hal tersebut dikuatkan oleh Sugiyarto (2005) bahwa suatu komunitas dikatakan 
mempunyai keanekaragaman jenis yang tinggi jika komunitas itu disusun oleh banyak jenis dengan kelimpahan yang sama atau hampir sama.

Apabila merujuk pada pendapat kategori Maharadatunkamsi (2011) tersebut hasil perhitungan indeks keanekaragaman makrofauna tanah yang ditemukan pada 6 stasiun pada lokasi penelitian di kawasan perkebunan cokelat Kecamatan Kalibaru, Kabupaten Banyuwangi yang tersajikan pada gambar 1 dapat dikatakan bahwa pada stasiun 1 dengan nilai indeks keanekaragaman 1,61 maka termasuk dalam kategori rendah, stasiun 2 dengan indeks keanekaragaman 1,85 termasuk ke dalam kategori rendah, pada stasiun 3 dengan nilai indeks keanekaragaman 1,82 termasuk dalam kategori rendah, pada stasiun 4 dengan nilai indeks keanekaragaman 1,97 termasuk ke dalam kategori rendah, pada stasiun 5 dan 6 termasuk dalam kategori sedang karena lebih dari 2 yakni 2,26 untuk stasiun 5 dan 2,02 untuk stasiun 6 .

\section{Kandungan C-Organik tanah.}

Suin (2012) menjelaskan bahan organik tanah sangat menentukan kepadatan populasi organisme tanah salah satunya adalah fauna tanah di mana semakin tinggi kandungan organik tanah maka semakin beranekaragaman fauna tanah yang terdapat pada suatu ekosistem. Komposisi dan jenis serasah daun menentukan jenis fauna tanah yang terdapat di daerah tersebut dan banyaknya tersedia serasah menentukan kepadatan fauna tanah. Material bahan organik merupakan sisa tumbuhan dan hewan organisme tanah, baik yang telah terdekomposisi maupun yang sedang terdekomposisi. Menurut Supriyadi (2008) kandungan bahan organik (C-organik) dalam tanah mencerminkan kualitas tanah, di mana kandungan bahan organik dikatakan sangat rendah apabila $<2 \%$, dan rendah apabila $>2 \%$, kandungan bahan organik yang berkisar $2-10 \%$ memiliki peranan yang sangat penting. Hasil uji tanah yang dilakukan disajikan dalam tabel 2.

Tabel 2 Kandungan C-organik tanah

\begin{tabular}{cccccccc}
\hline & & \multirow{6}{c}{ Rerata } & \multicolumn{5}{c}{ Kriteria } \\
\cline { 4 - 7 } No & Lokasi & C-Organik tanah & $\begin{array}{c}\text { SR } \\
(<\mathbf{1})\end{array}$ & $\begin{array}{c}\mathbf{R} \\
(\mathbf{1 - 2})\end{array}$ & $\begin{array}{c}\mathbf{S} \\
(\mathbf{2 - 3})\end{array}$ & $\begin{array}{c}\mathbf{T} \\
(\mathbf{3}-5)\end{array}$ & $\begin{array}{c}\text { ST } \\
(>\mathbf{5})\end{array}$ \\
\hline 1 & Stasiun 1 & 11,00 & - & - & - & - & \\
2 & Stasiun 2 & 13,69 & - & - & - & - & \\
3 & Stasiun 3 & 8,66 & - & - & - & - & \\
4 & Stasiun 4 & 8,02 & - & - & - & - \\
5 & Stasiun 5 & 13,98 & - & - & - & - \\
6 & Stasiun 6 & 14,42 & - & - & - & - & \\
\hline
\end{tabular}

Keterangan: SR: Sangat Rendah, R: Rendah, S: Sedang,T: Tinggi, ST:Sangat Tinggi

Berdasarkan tabel 2 dapat diketahui bahwa hasil uji C-Organik tanah pada stasiun I, II, III, IV, V,dan VI berada dalam kriteria sangat tinggi, yaitu antara 8,02 sampai 14,42. menurut Atmojo (2003) C-organik berperan dalam biologi tanah yaitu sebagai sumber energi untuk mesofauna tanah yang menyebabkan aktivitas dan populasi meningkat sehingga dapat berperan dalam proses humifikasi dan mineralisasi atau pelepasan hara, bahkan ikut bertanggung jawab terhadap pemeliharaan struktur tanah.

Berdasarkan hasil penelitian pada perhitungan tentang hasil uji C-Organik tanah dapat diketahui bahwa tanah pada lokasi penelitian menunjukkan kriteria tanah yang tergolong subur karena nilai C-Organik tanah yang tinggi. Menurut Hanafiah (2013) kesuburan tanah juga dipengaruhi oleh ketersediaan hara atau C-Organik tanah, rendahnya ketersediaan hara mencerminkan rendahnya kesuburan tanah, sehingga keberadaan makrofauna tanah sebagai perombak bahan organik sangat menentukan ketersediaan hara dalam menyuburkan tanah. Semakin tinggi kandungan bahan organik dalam tanah maka tanah tersebut akan semakin subur begitu juga sebaliknya. 
Menurut Supriyadi (2008) kandungan bahan organik (C-organik) dalam tanah mencerminkan kualitas tanah, di mana kandungan bahan organik dikatakan sangat rendah apabila $<2 \%$, dan rendah apabila $>2 \%$, kandungan bahan organik yang berkisar $2-10 \%$ memiliki peranan yang sangat penting. Bahan organik tanah merupakan indikator dari kualitas tanah, karena merupakan sumber dari unsur hara. Bahan organik tanah erat kaitannya dengan kondisi tanah baik secara fisik, kimia dan biologis yang selanjutnya turut menentukan produktivitas suatu lahan (Waluyaningsih, 2008). Menurut Hanafiah (2013) kesuburan tanah juga dipengaruhi oleh ketersediaan hara, rendahnya ketersediaan hara mencerminkan rendahnya kesuburan tanah sehingga keberadaan makrofauna tanah sebagai perombak bahan organik sangat menentukan ketersediaan hara dalam menyuburkan tanah.

Suin (2012) menjelaskan bahan organik tanah sangat menentukan kepadatan populasi organisme tanah salah satunya adalah fauna tanah di mana semakin tinggi kandungan organik tanah maka akan semakin beranekaragaman fauna tanah yang terdapat pada suatu ekosistem. Komposisi dan jenis serasah daun menentukan jenis fauna tanah yang terdapat di daerah tersebut dan banyaknya tersedia serasah menentukan kepadatan fauna tanah. Hairiah, Kasniari, Noordwijk, Foresta, Syekhfani, (1996) melaporkan bahwa keadaan tanah yang optimal bagi pertumbuhan tanaman diperlukan adanya bahan organik tanah di lapisan atas paling sedikit 2\%. Agar mempertahankan keadaan bahan organik tanah tersebut, tanah pertanian harus selalu ditambahkan bahan organik minimal 8-9 ton/ha setiap tahunnya. Kandungan C-organik tanah tinggi menunjukkan bahwa tingkat kesuburan tanah yang tinggi, begitu juga sebaliknya Dari uraian di atas menunjukkan bahwa penggunaan pestisida sistetik pada lokasi penelitian relatif rendah. Salah satu faktor yang mempengaruhi kesuburan tanah adalah penggunaan pestisida sintetik.

Meningkatnya keanekaragaman makrofauna di dalam tanah dengan meningkatnya kandungan bahan organik tanah dan dominansi vegetasi bawah disebabkan oleh karena bahan organik tanah maupun sisa-sisa tanaman dari vegetasi bawah dapat dimanfaatkan oleh makrofauna di dalam tanah sebagai sumber makanannya (Sugiyarto, 2000). Suin (2012) menjelaskan bahan organik tanah sangat menentukan kepadatan populasi organisme tanah salah satunya adalah fauna tanah di mana semakin tinggi kandungan organik tanah maka akan semakin beranekaragaman fauna tanah yang terdapat pada suatu ekosistem.

\section{Kandungan Organophosfat tanah}

Untung (2006) mengemukakan bahwa penggunaan pestisida sintetik berdampak negatif pada keseimbangan ekosistem. Rahmawati (2012) menambahkan penggunaan pupuk kimia sintetik dan insektisida sintetik secara berlebihan dapat menimbulkan berbagai permasalahan. Permasalahan yang ditimbulkan yaitu bisa pencemaran pupuk kimia dan pestisida, penurunan kualitas lahan, penurunan kesehatan manusia akibat mengonsumsi hasil pertanian yang banyak mengandung residu dari bahan-bahan kimia, serta bisa menyebabkan kepunahan pada jenis-jenis makrofauna tanah tertentu yang berdampak pada kurangnya keanekaragaman jenis makrofauna tanah yang ada di ekosistem tersebut. Hasil Uji Residu Pestisida disajikan pada tabel 3 di bawah ini.

Tabel 3 Hasil analisis organofosfat

\begin{tabular}{ccccc}
\hline \multirow{2}{*}{ No } & Lokasi & Jenis oegaophosphat & $\begin{array}{c}\text { Hasil Analisis } \\
(\boldsymbol{\mu g} / \mathbf{1 0 0} \mathbf{g})\end{array}$ & Keterangan \\
\hline \multirow{2}{*}{ Stasiun 1 } & Carbofuran & $\mathbf{5 , 4 0 7 2}$ & Tertinggi \\
& Diamidafos & 4,2959 & \\
& Glyphosat & 4,1062 & \\
& Buprofezin & 3,0059 & \\
& Mevinphos & 2,0814 & \\
\hline
\end{tabular}




\begin{tabular}{|c|c|c|c|c|}
\hline No & Lokasi & Jenis oegaophosphat & $\begin{array}{l}\text { Hasil Analisis } \\
(\mu \mathrm{g} / 100 \mathrm{~g})\end{array}$ & Keterangan \\
\hline \multirow{9}{*}{2} & \multirow{9}{*}{ Stasiun 2} & Dichlorvos & 2,0204 & \multirow{9}{*}{ Tertinggi } \\
\hline & & benthlavalicarb & 2,0015 & \\
\hline & & Carbofuran & 5,2559 & \\
\hline & & Diamidafos & 4,1649 & \\
\hline & & Glyphosat & 3,8817 & \\
\hline & & Dichlorvos & 2,1357 & \\
\hline & & Buprofezin & 2,8875 & \\
\hline & & Mevinphos & 1,9512 & \\
\hline & & benthlavalicarb & 1,8676 & \\
\hline \multirow[t]{7}{*}{3} & \multirow[t]{7}{*}{ Stasiun 3} & Carbofuran & 5,5644 & \multirow[t]{7}{*}{ Tertinggi } \\
\hline & & Diamidafos & 4,4320 & \\
\hline & & Glyphosat & 4,3400 & \\
\hline & & Buprofezin & 3,1292 & \\
\hline & & Mevinphos & 2,2170 & \\
\hline & & Dichlorvos & 2,4394 & \\
\hline & & benthlavalicarb & 2,1409 & \\
\hline \multirow[t]{7}{*}{4} & \multirow[t]{7}{*}{ Stasiun 4} & Carbofuran & 6,6645 & \multirow[t]{7}{*}{ Tertinggi } \\
\hline & & Glyphosat & 5,9838 & \\
\hline & & Diamidafos & 5,3852 & \\
\hline & & Buprofezin & 3,9941 & \\
\hline & & Mevinphos & 3,1712 & \\
\hline & & benthlavalicarb & 3,1223 & \\
\hline & & Dichlorvos & 2,7698 & \\
\hline \multirow[t]{7}{*}{5} & \multirow[t]{7}{*}{ Stasiun 5} & Carbofuran & 4,4192 & \multirow[t]{7}{*}{ Tertinggi } \\
\hline & & Diamidafos & 3,3497 & \\
\hline & & Glyphosat & 2,6295 & \\
\hline & & Buprofezin & 2,2290 & \\
\hline & & Mevinphos & 1,2242 & \\
\hline & & benthlavalicarb & 1,1198 & \\
\hline & & Dichlorvos & 1,8476 & \\
\hline \multirow[t]{7}{*}{6} & \multirow[t]{7}{*}{ Stasiun 6} & Carbofuran & 3,5645 & \multirow[t]{7}{*}{ Tertinggi } \\
\hline & & Diamidafos & 2,6992 & \\
\hline & & Dichlorvos & 1,6237 & \\
\hline & & Buprofezin & 1,5575 & \\
\hline & & Glyphosat & 1,9111 & \\
\hline & & benthlavalicarb & 1,1198 & \\
\hline & & Mevinphos & 0,4839 & \\
\hline
\end{tabular}

Berdasarkan tabel 3 diketahui bahwa yang mendominasi atau nilai paling tinggi organofosfat yang ada pada kawasan berdasarkan uji laboratorium pada stasiun 1, perkebunan cokelat adalah jenis Dichlorvos, 3, 4, 5, dan 6 adalah Carbufuran sedangkan Diamidafos, Carbofuran, Mevinphos, Buprofezin, stasiun 6 adalah Diamidafos. Handayanto, Glyphosat, dan Benthlavalicarb. Organofosfat (2009) mengungkapkan Salah satu bahan kimia 
yang digunakan dalam pertanian adalah jenis insektisida, herbisida, dan pestisida sintetik. Penggunaan bahan kimia tersebut dalam jangka waktu yang lama akan meninggalkan residu yang berdampak negatif baik bagi tanah, tanaman, dan organisme lain yang ada di lingkungan tersebut. Salah satu residu yang berdampak negatif terhadap kehidupan mesofauna dan makrofauna tanah adalah organofosfat. Organofosfat merupakan kelompok insektisida terbesar yang sangat beracun bagi serangga dan bersifat sebagai racun kontak, racun perut, dan fumigant.

Tingkat residu pestisida di lingkungan dipengaruhi oleh beberapa faktor, seperti suhu lingkungan, kelarutanya dalam air, serta penyerapanya oleh koloid bahan organik tanah. Hasil penelitian menunjukkan organofosfat yang ada pada kawasan perkebunan cokelat adalah jenis Dichlorvos, Diamidafos, Carbofuran, Mevinphos, Buprofezin, Glyphosat, dan Benthlavalicarb. Organofosfat yang mendominasi atau nilai paling tinggi berdasarkan uji laboratorium pada stasiun 1, 3, 4, 5, dan 6 adalah Carbufuran sedangkan stasiun 6 adalah Diamidafos. Pestisida dalam tanah memiliki persisten atau sukarnya pestisida terurai dalam tanah yang berbeda jangka waktu paruhnya.

\section{Kesimpulan}

Berdasarkan hasil penelitian dapat disimpulkan bahwa jenis makrofauna tanah yang diketemukan adalah Tachyta angulata, Cryptocercus garciei, Lymnea rubigenosa, Odontoponera denticulata, Sigmoria trimaculata, Pirata piratichus, Sitena sp., Grillus sp., Scolopendra gigantea, Forficula auricularia, Hydrochara soror, Leptocarisa aculata, Trigoniulus corallinus, Odontomanchus sp., Lumbricus rubellus , Phyllopaga sp., Componatus arogans, Geophilus sp., Gryllotalpa grillotalpa, Ploiaria sp.

Indeks keanekaragaman makrofauna tanah berkisar antara 1,61 sampai 2,26. Indeks keanekaragaman Makrofauna tanah tertinggi terdapat pada stasiun penelitian 5 yaitu 2,26. Berdasarkan nilai Indeks keanekaragaman pada stasiun penelitian I, II, dan III berada dalam kategori rendah dan stasiun IV, V, dan VI dalam kategori sedang.

Kandungan C-organik pada lokasi penelitian sangat tinggi namun indeks keanekaragaman makrofauna tanah rendah, rendahnya keanekaragaman makrofauna tanah dimungkinkan karena adanya organophosfat yang ada pada tanah.

\section{Daftar Pustaka}

Agustina, Lyli dkk. 2007. Preferensi Berbagai Jenis Makrofauna Tanah Terhadap Sisa Bahan Organik Tanaman pada Intensitas Cahaya Berbeda. Biodiversitas, 7(4): 96-100.

Ariani, Desi. 2009. Komposisi Komunitas Makrofauna Tanah untuk Memantau Kualitas Tanah Secara Biologis pada Areal Perkebunan PTPN Sampali Kecamatan Percut Sei Tuan. Bioteknologi 4 (1): 20-27.

Atmojo, S. W. 2003. Peranan Bahan Organik terhadap Kesuburan Tanah dan Upaya Pengelolaannya. Pengukuhan Guru Besar Ilmu Kesuburan Tanah. Universitas Sebelas Maret. Surakarta.

Boror, D. J,. C. A. Triplehorn \& N.F. Johnson. 1997. Pengenalan Pelajaran Serangga. Yogyakarta: Gadjah Mada University Press: 1083 hal.

Brussaard, L. 1998. Soil Fauna, Guilds, Functional Groups and Ecosystem Processes. Appl. Soil Ecol. 9: 123-136.

Bruyn et al. 1997. The Status of Soil Macrofauna as Indicators of Soil Health to Monitor the Sustainability of Australian Agricultural Soil. Ecological Economics 23 (1997) 167-178.

Fitrahtunnisa dkk. 2002. Perbandingan Keanekaragaman dan Predominasi Fauna Tanah dalam Proses Pengomposan Sampah Organik. Jurnal Bumi Lestari. 13(2): 413-421.

Fachrul, M. F. 2012. Metode Sampling Bioekologi. Edisi I Cetakan III. Jakarta: Bumi Aksara.

Giller, K.E., M.H. Beare, P. Lavelle, A.M.N. Izac and M.J. Swift. 1997. Agricultural Intensification, 
Soil Biodiversity and Agroecosystem Function. Appl. Soil Ecol. 6: 3-16.

Hanafiah, K.A. 2013. Dasar-Dasar Imu Tanah. Jakarta: PT. Raja Grafindo Persada.

Hilwan. 2013. Keanekaragaman Mesofauna dan Makrofauna Tanah pada Areal Bekas Tambang Timah di Kabupaten Belitung, Provinsi Kepulauan Bangka-Belitung. Jurnal Silvilkultur Tropika. 4(1): 35-41.

Imawan, Hardi. 2013. Keanekaragaman Makrofauna Tanah pada Vegetasi Pohon Pinus (Pinus merkusii) di Kesatuan Pemangkuhan Hutan (KPH) Wisata Alam Coban Rondo Kecamatan Pujon Kabupaten Malang. Skripsi Pendidikan Biologi UMM. Tidak diterbitkan. Malang.

Ibrahim, Hasan. 2014. Keanekaragaman Mesofauana Tanah Daerah Pertanian Apel Desa Tulungrejo Kecamatan Bumiaji Kota Batu Sebagai Bioindikator Kesuburan Tanah dan Bahan Ajar Biologi SMA. Skripsi Pendidikan Biologi UMM. Tidak diterbitkan. Malang.

Leksono, A.S 2011. Keanekaragaman Hayati. Malang: UB Press.

Maharadatunkamsi. 2011. Profil Mamalia Kecil Gunung Slamet Jawa Tengah. Jurnal Biologi Indonesia, 7(1): 171-185.

Merlim, Analy de Oliveira, José Guilherme Marinho Guerra; Rodrigo Modesto Junqueira. Adriana Maria de Aquino. 2005. Soil Macrofauna in Cover Crops of Figs Grown Under Organic Management. Sci. Agric. (Piracicaba, Braz.), 62(1): 57-61.

Miguran, A.E. 2004. Measuring Biological Diversity. Australia: Black Well Publising.

Ningsih, Dwi Septi. 2014. Analisis Keanekaragaman Semut di Daerah Pemukiman Daerah Aliran Sungai (Das) Brantas Hulu Dusun Wukir Sebagai Sumber Belajar Biologi SMA Kelas X. Skripsi. Tidak diterbitkan. Pendidikan Biologi UMM. Malang.

Njira, Keston Oliver Willard \& Nabwami, Janet. 2013. Soil Management Practices that Improve Soil Health: Elucidating their Implications on Biological Indicators. Journal of Animal \& Plant Sciences. 18(2): 2750-2760

Putra, Muhammad dkk. 2012. Makrofauna Tanah Pada Ultisol di Bawah Tegakan Berbagai Umur Kelapa Sawit (Elaeis Guineensis Jacq.) Jurnal Penelitian UNRI: Riau.

Nusroh, Zaidatun. 2007. Studi Diversitas Makrofauna Tanah di Bawah Beberapa Tanaman Palawija yang Berbeda di Lahan Kering pada Saat Musim Penghujan. Jurnal Penelitian UNS: Surakarta.

Odum, E. P. 1998. Dasar-Dasar Ekologi. Edisi Ketiga. Terjemahan Tjahjono Samingan. Gadjah Mada University Press. Yogyakarta. 967 hal

Peritika, M. Z. 2010. Keanekaragaman Makrofauna Tanah pada Berbagai Pola Agroforestri Lahan Miring di Kabupaten Wonogiri, Jawa Tengah. Skripsi. Tidak diterbitkan. Surakarta: Jurusan Biologi. Fakultas Matematika dan Ilmu Pengetahuan Alam. Universitas Sebelas Maret.

Rahayuningsih dkk. 2012. Persebaran dan Keanekaragaman Herpetofauna dalam Mendukung Konservasi Keanekaragaman Hayati di Kampus Sekaran Universitas Negeri Semarang. Indonesian Journal of Conservation.1(1): 1-10.

Rahmawati, D. A. 2012. Upaya Peningkatan Pendapatan Petani Melalui Penggunaan Pupuk Organik (Studi Kasus Pada Petani Jagung di Desa Surabayan, Kecamatan Sukodadi, Kabupaten Lamongan). Malang: Program Studi Agribisnis. Jurusan Sosial Ekonomi Pertanian. Fakultas Pertanian. Universitas Brawijaya.

Samudra, Budi dkk. 2013. Kelimpahan dan Keanekaragaman Arthropoda Tanah di Lahan Sayuran Organik "Urban Farming”. Prosiding Seminar Nasional Pengelolaan Sumberdaya Alam dan Lingkungan 2013. 
Setyawati, Rima Try dkk. 2013. Keanekaragaman Cacing Tanah (Oligochaeta) pada Tiga Tipe Habitat di Kecamatan Pontianak Kota. Protobiont. 2 (2): 56-62.

Soegianto, A. 1994. Ekologi Kuantitatif. Surabaya: Usaha Nasional.

Sugiyarto dkk. 2002. Biodiversitas Hewan Permukaan Tanah pada Berbagai Tegakan Hutan di Sekitar Goa Jepang, BKPH Nglerak, Lawu Utara, Kabupaten Karanganyar. Biodiversitas, 7 (4): 196-200.

Sugiyarto., Efendi. M., Mahajoeno. E., Sugito. Y., Handayanto. E., Agustina. L. 2007. Preferensi Berbagai Jenis Makrofauna Tanah terhadap Sisa Bahan Tanaman pada Intensitas Cahaya Berbeda. Biodiversitas, 7 (4): 96-100.

Sugiyarto, Uteni Wulandari, Wiryanto. 2005. Pengaruh Keanekaragaman Mesofauna dan Makrofauna Tanah terhadap Dekomposisi Bahan Organik Tanaman di Bawah Tegakan Sengon (Paraserianthes falcataria). Bioteknologi 4 (1): 20-27.

Sugiyarto. 2000. Keanekaragaman Makrofauna Tanah pada Berbagai Umur Tegakan Sengondi RPH Jatirejo, Kabupaten Kediri. Biodiversitas. 1(2): 47-53.

Suheriyanto, D. 2013. Keanekaragaman Makrofauna Tanah di Taman Nasional Bromo Tengger Semeru sebagai Bioindikator Tanah Bersulfur Tinggi. Jurnal Lingkungan. 34-40.

Suhardjono, Y. R. 1997. Arthropoda Tanah, Artinya Bagi Tanah, Makalah pada Kongres dan Simposium Entomologi V, Bandung 24-26 Juni 1997. Hal:10.

Suin, Muhammad Nurdin. 2012. Ekologi Hewan Tanah. Bandung: Bumi Aksara.

Sukarsono. 2009. Pengantar Ekologi Hewan: Konsep, Perilaku, Psikologi, dan Komunikasi. Malang: UMM Press.

Suwondo. 2007. Dinamika Kepadatan dan Distribusi Vertikal Arthropoda Tanah pada Kawasan Hutan Tanaman Industri. Jurnal Pilar Sains. 6(2): 41-50.

Suwondo. 2002. Komposisi dan Keanekaragaman Mikroartropoda Tanah sebagai Bioindikator Karakteristik Biologi pada Tanah Gambut. Program Studi Biologi PMIPA, FKIP, Universitas Pendidikan Indonesia.

Ummi. Z. R. 2007. Studi Keanekaragaman Serangga Tanah di UPT Balai Konservasi Tumbuhan Kebun Raya Purwodadi-LIPI (Desa Purwodadi Kecamatan Purwodi Kabupaten Pasuruan). Skripsi. Tidak Diterbitkan. Jurusan Biologi Malang, Universitas Islam Negeri.

Untung, K. 2006. Pengantar Pengelolaan Hama Terpadu. Yogyakarta: Gadjah Mada University Press. Wahyudi dkk. 2008. Panduan lengkap Kakao Manajenen Agribisnis dari Hulu Hingga Hilir. Jakarta: Kemetrian Pertanian RI.

Widyati, Enny. 2013. Pentingnya Keragaman Fungsional Organisme Tanah terhadap Produktivitas Lahan. Tekno Hutan Tanaman. 6 (1): 29-37.

Wulandari, Uteni dkk. 2005. Pengaruh Keanekaragaman Mesofauna dan Makrofauna Tanah terhadap Dekomposisi Bahan Organik Tanaman di Bawah Tegakan Sengon (Paraserianthes falcataria). Jurnal Penelitian UNS: Surakarta. 